\section{Gen som disponerer for schizofreni}

Neuregulin 1 (NRG1) er en vekstfaktor med betydning for utvikling av blant annet nerveceller og myelinisering. Genet som koder for NRG1, er ett av de beste kandidatgenene for schizofreni.

Resultatene fra en ny studie viste sikkert $ø k t$ risiko for schizofreni for flere genvarianter (polymorfismer) av NRG1, mens én bestemt variant beskyttet mot sykdommen (Arch Gen Psychiatry 2009; 66: 828-837). Studien er fra Nord-Sverige, der befolkningen er relativt stabil og homogen. Det er mulig at de genene som disponerer for schizofreni, er ulike i ulike befolkningsgrupper, og at dette er grunnen til at tidligere studier av NRG1-genet og schizofreni har gitt varierende resultater.

\section{Genmutasjon assosiert med epilepsi}

Minst $40-50 \%$ av epilepsiformene er idiopatiske, med sannsynlig genetisk bakgrunn. Identifisering av genetiske og patofysiologiske mekanismer involvert i epilepsiutvikling vil være nyttig for utvikling av medikamenter.

Forskere har nå påvist at en mutasjon i genet ATP1A3 (Proc Natl Acad Sci USA 2009; 106: 14085-90). Dette genet koder for en $\mathrm{Na}^{+}, \mathrm{K}+-$ ATPase som regulerer natriumog kaliumbalansen i hjernen.

Forskerne benyttet musemodeller og fant at individer med denne mutasjonen hadde redusert aktivitet i $\mathrm{Na}^{+}, \mathrm{K}^{+}-\mathrm{ATP}$ asen. Disse musene hadde redusert krampeterskel, som ved epilepsi, og dette kunne motvirkes ved tilførsel av normalt $\mathrm{Na}^{+}, \mathrm{K}^{+}-$ ATPase. Forskerne konkluderer med at dette er en mekanisme bak idiopatisk epilepsi, og at det kan ha betydning også hos mennesker.

\section{Dyp hjernestimulering ved cerebral parese}

Dyp hjernestimulering kan gi bedre bevegelighet og høyere livskvalitet for noen pasienter med en subtype av cerebral parese (dystoni-koreoatetose). Det viser en ny studie (Lancet Neurol 2009; 8: 709-17).

13 pasienter fikk utført dyp hjernestimulering. De ble undersøkt før operasjonen og 12 måneder etter. Dyp hjernestimulering resulterte i vedvarende bedring i motoriske symptomer i mesteparten av kroppen etter ett år - men det var stor variasjon mellom pasientene.

\title{
P-piller og tromboserisiko
}

\author{
Risikoen for venetrombose ved p-pil- \\ lebruk har sammenheng med østro- \\ gendosen og progesterontypen.
}

Man har antatt at en reduksjon i østrogendosen i p-piller fra $50 \mu \mathrm{g}$ til $30 \mu \mathrm{g}$ ville gi lavere risiko for venetrombose, men det er motstridende resultater. Ytterligere redusert risiko ved en dose på $20 \mu \mathrm{g}$ er ikke dokumentert. Nå har nederlandske og danske forskere i hver sin studie undersøkt sammenhengen mellom ulike typer p-piller og risikoen for venetrombose hos kvinner under 50 år $(1,2)$.

I Nederland har man gjort en pasient-kontroll-studie med 1524 kvinner med venetrombose og 1760 kontrollkvinner. I den danske kohortstudien tok man utgangspunkt i forskrivnings- og sykdomsregistre som omfatter 10,4 millioner kvinneår. I en tredel av disse brukte kvinnene p-piller. I begge studiene ble det påvist forhøyet risiko for venetrombose ved bruk av p-piller, og risikoen økte med økende østrogendose i kombinasjonspillene $(20 \mu \mathrm{g}, 30-40 \mu \mathrm{g}$, $50 \mu \mathrm{g})$. Risikoen var dessuten avhengig av progesterontype - for drospirenon og desogestrel var den høyere enn for levonorgestrel.

- I de to studiene har brukt forskjellige epidemiologiske metoder, men man kommer likevel til forbausende like resultater, sier leder Kirsten Myhr ved RELIS Øst legemiddelinformasjonssenter. - De bekrefter tidligere studier, som har vist at de ulike progesteronene innebærer forskjellig tromboserisiko. Kombinasjonen lavdose østrogen/levonorgestrel har lavest risiko og bør være førstevalg. Studiene bekrefter dessuten at det er lavere risiko når østrogendosen reduseres. Kombinasjoner med drospirenon og cyproteron har samme risiko som desogestrel. Risikoen er størst de første månedene etter oppstart. I piller og spiraler med bare progesteron er det ingen økt risiko for trombose. Det er interessant at en stor postmarketingstudie som produsenten av Yasmin har gjort og som mange har vært kritiske til, ikke viste denne økte risikoen med drospirenon, sier Myhr.

\section{Trine B. Haugen}

trine.b.haugen@hf.hio.no

Tidsskriftet

\section{Litteratur \\ 1. van Hylckama Vlieg A, Helmerhorst FM, Vanden- broucke JP et al. Hormonal contraception and risk of venous thromboembolism: national follow-up study. BMJ 2009; 339: b2921. \\ 2. Lidegaard $\emptyset$, Løkkegaard $E$, Svendsen $A L$ et al. Hormonal contraception and risk of venous throm- boembolism: national follow-up study. BMJ 2009. 339: b2890.}

\section{Hurtigtest av Chlamydia hos menn}

\section{En ny hurtigtest for Chlamydia tra- chomatis i urin hos menn er enkel i bruk, men vil neppe erstatte dagens chlamydiadiagnostikk i Norge.}

I diagnostikk av genital Chlamydia brukes vanligvis nukleinsyreamplifikasjonsmetoder. Disse metodene er mer sensitive enn enzymimmuntester, men det tar noen timer før resultatet foreligger. Nå har engelske forskere evaluert en ny hurtigtest for påvisning av Chlamydia trachomatis hos menn (1).

Studien var prospektiv og omfattet 1211 menn med eller uten symptomer på uretritt. Chlamydiatesting av urinprøver ble utført både med polymerasekjedereaksjon (PCR) og med hurtigtesten (Chlamydia Rapid Test), som ga prøveresultatet innen en time. Sammenliknet med PCR-metoden var sensitivitet, spesifisitet, positiv og negativ prediktiv verdi for hurtigtesten henholdsvis $83 \%, 99 \%, 84 \%$ og $98 \%$. Det var dessuten en signifikant korrelasjon mellom chlamydianivået i prøven og det visuelle signalet $\mathrm{i}$ hurtigtesten.

- Eksisterende hurtigtester for påvisning av Chlamydia har for lav sensitivitet og spesifisitet sammenliknet med dagens genteknologiske metoder, sier overlege Svein
Arne Nordbø ved Avdeling for medisinsk mikrobiologi, St. Olavs hospital.

Den nye hurtigtesten kan skilte med en sensitivitet som ifølge forfatterne er $10-20 \%$ høyere enn konkurrentenes. En vesentlig årsak til dette er at prøvetakingsutstyret sikret undersøkelse av kun de første få milliliter urin, der chlamydiakonsentrasjonen er høyest.

- Den største svakheten ved denne studien er at testene ikke er utført på samme materiale og at den ikke er randomisert. Det beste prøvematerialet er kun testet med hurtigtesten, som da har et fortrinn i forhold til PCR-metoden. Likevel er sensitiviteten ikke imponerende: $84 \%$ hos symptomatiske og $78 \%$ hos asymptomatiske menn. Hurtigtesten kan i beste fall anvendes på høyprevalensgrupper, men er neppe noen utfordrer til dagens chlamydiadiagnostikk i Norge, sier Nordbø.

\section{Trine B. Haugen \\ trine.b.haugen@hf.hio.no \\ Tidsskriftet}

\section{Litteratur}

Nadala E-C, Goh BT, Magbanua JP et al. Performance evaluation of a new rapid urine test for chlamydia in men: prospective cohort study. BM 2009; 339: b2655. 